\title{
The Realization of Text Coherence Through Personal Pronouns in Albanian, English, and German language
}

\author{
Jetmire ALIU \\ PhD Candidate, University of Tetova, North Macedonia \\ Email: faton.aliu@live.com
}

\begin{abstract}
'Coherence' as a linguistic notion is one of the seven basic criteria of textuality (Dressler 1981). There are many linguistic elements through them coherence can be achieved, but the focus of this article will be the personal pronoun in the Albanian, English, and German language. The reason of conducting such a contrastive research consists of three guidelines: First, although Albanian, German and English belong to the same language family: Indo-European, also they are inflectional languages, but they have their own mechanism expressing linguistic phenomena. Secondly, the Albanian language, building an independent group within the Indo-European family group, provides some differences in the morpho-syntactic level compared to German and English as languages of the same group. Third, personal pronouns are cohesion means in German and English, but they are coherence means in Albanian.This article focuses not only to express the linguistic differences of the realization of text coherence trough personal pronouns in Albanian, German and English, but also builds an methodological-didactic frame, especially for learners of German and English to avoid mistakes in the process of text constitution in these languages.
\end{abstract}

Keywords: Personal pronouns, text coherence, cohesion, Albanian, German, English.

DOI: $10.7176 / J L L L / 84-01$

Publication date: December $31^{\text {st }} 2021$

\section{Introduction}

The aim of this article is to treat the problem of the realization of text coherence through personal pronouns in Albanian, German, and English language. Especially nowadays when in North Macedonia and the whole Balkan region English and German have become primary languages in the life and school.

Being a teacher of the Albanian language for more than 1 decade, I have realized that the curricula offer only a surface treat of the grammar knowledge. Even the teachers do not go beyond the curricula. Grammar phenomena are taught only formally, they are not treated within the context and everyday situations. Languages, as Humbold says, are not static entities, but very dynamic and we teachers must do our job good and right.

Another problem is that the Albanian linguistics is still firmly attached to traditionalism (Probably because the world languages like German and English were not valued in the era of communism). Among the few who have committed some researches in the new linguistic disciplines is the professor Arbër Çeliku and his specialization is text linguistics, comparative linguistics, and intercultural communication. Therefore, the goal has been set to commit a pioneer work in the Albanian linguistics, especially in the field of text coherence and its realization through personal pronouns. An interesting switching phenomenon among the Albanian language on the one hand, and German and English on the other hand.

\section{2 'Text cohesion' and 'text coherence' in the current linguistic discussion}

The concept of coherence is closely related to the concept of cohesion. Both are traditionally viewed as terms in text linguistics. They are text-centered criteria of textuality (Beaugrande / Dressler 1981, Vater 1996, Dibra / Varfi 1999).

The terminological delimitation of cohesion and coherence is not uniform. Both terms are used differently in individual phases of textual linguistic development. The reason for this is the changing focus in text-linguistic research.

Every concrete spoken or written text has a linear phonetic or graphic structure that is formed according to certain rules. This is called text cohesion. Text cohesion, however, is based on "grammatical dependencies" (Heinemann/Viehweger 1991:76). These grammatical dependencies include, for example, "pronominalizations and the occurrence of conjunctions", but also "phonological, morphological and lexical phenomena that establish a connection between parts of text or utterance" (Rickheit / Schade 2000: 275). The phonological features include primarily the means of lyric poetry in the form of rhymes and stress patterns, in the morpho-syntactic area the tense and purely syntactic means of cohesion anaphora, substitutions, ellipses, conjunctions and, as lexicon elements, repetitions (ibid. 277).

Text coherence, on the other hand, is "the continuity of the content in the sense of a 'configuration of meaning" [...]. Coherence therefore only arises through the linking of the knowledge prepared in the text (the 'text world) with stored' world knowledge 'of the communication partners"(Heinemann/Viehweger, ibid., 76). According to 
today's linguistic discussion, the decision of where the text begins and ends to be a 'text' does not depend on cohesion, but on coherence. It goes without saying that a text should have ample means of cohesion and should be stylistically well designed, should have a global overall structure and a transparent approach, but that is not sufficient for a text with a communicative function. This is ensured by the coherence, which, as Adamzik (2004: 58) notes, is "' a regulative principle 'of text production and reception", which means that it primarily ensures the reconstruction of the textual context.

According to Çeliku $(2009,19)$ "Coherence guaranties the semantic-logical relations of what we say and the texts in general, while cohesion the formal-grammatical relations, especially in written texts”. He (ibidem, p. 24) distinguishes between Coherence A (the implicit one) and Coherence B (the explicit one). Achieving coherence A occurs naturally, only linguistic knowledge and normal perception of objective reality are sufficient, while to achieve Coherence B, it is necessary to know the context, to have a specific knowledge on a certain field, to detect ironic and diplomatic speech, etc.

As a result, coherence plays a very important role in the conceptual constitution of texts and discourses. But this conceptual constitution can be different from language to language because every language has different mechanism in expressing phenomena. If we compare the Albanian language with the German and English languages, we can see these contrasts. As an good example are personal pronouns; they act as elements of the text cohesion in German and English, but elements of text coherence in Albanian. We continue to deal with this issue in the next chapters.

\section{Methodology of the work \\ 3.1 Corpus}

In order to have a clearer picture of the state of the use of personal pronouns in the textual constitution, online newspaper and media sources have been collected, as well as excerpts from books for analysis by German authors such as: Hermann Hesse, Nur wer liebt, ist lebendig (Alive is only he who loves).

Another source of data is the Grammar of the Academy of Sciences of Albania (2006) from which the ways of using personal pronouns and their textual function have been exhaustively examined.

The material used from the above-mentioned sources enabled us to build a dense linguistic framework for the use of personal pronouns in the text, but also for outlining new paths in the field of comparative linguistics and the methodological-didactic spectrum of foreign language learning. such as English and German, which are well established in the education system in Northern Macedonia and the entire Balkan region.

\subsection{Presentation of research results}

The pronoun is an important means of text constitution in the three languages and thus "a kind of seek instruction" (Linke/Nussbaumer 2000:310), which has an anaphoric and a cataphoric function in the text. A pronoun is used anaphorically in the sense that it refers to a reference expression mentioned earlier in the text (The princess ... she) and cataphorically in the sense that it refers to already known reference (She is a wise woman ... Maria). Thus, the pronoun serves to maintain continuity of meaning in the text (Çeliku 2009:95). In Albanian, this is even more implicit than in German and English. The analysis of the following example will show this:

1) Mein Freund Konstantin Silbernagel stand mit allen Mädchen der Nachbarschaft gut, aber er hatte keinen Schatz. Wo er eine stehen und gehen sah, war er mit einem Gruß, mit einem Witz oder mit einer Freundlichkeit und vertraulichen Neckerei zur Hand, und die Mädchen standen dann, sahen ihm nach und hatten ihr Wohlgefallen an ihm; er hätte jede von ihnen haben können. Aber er wollte nicht [...].

(Hermann Hesse: Nur wer liebt, ist lebendig. Frankfurt/M. p. 84)

1') My friend Konstantin Silbernagel was on good terms with all the girls in the neighborhood, but he had no sweetheart. Wherever he saw one standing and walking, he was at hand with a greeting, with a joke or with a kindness and confidential teasing, and the girls then stood, looked after him and had their pleasure with him; he could have had any of them. But he did not want [...].

(Translation J. A.)

1') Shoku im Konstantin Silbernageli i kishte mirë punët me të gjitha vajzat e fqinjësisë, por $\emptyset$ nuk kishte të dashur. Kudo që $\varnothing$ shihte ndonjë vajzë, $\varnothing$ e përshëndeste miqësisht, ose bënte ndonjë gallatë të çastit, e cila u pëlqente atyre. Ai mund ta kishte çdonjërën prej tyre, por $\emptyset$ nuk donte [...].

(H. Hesse: I gjallë është vetëm ai që dashuron. Skopje 2006.

Translation: Ariton Baftiri, p. 81)

Since the pronouns in German and English are of great importance to avoid repetition and that this does not have to be a characteristic of a bad text, moreover, the subject cannot be omitted in the German and English sentence (as in the above text, where the only possibility is to be able to resume Konstantin Silbernagel in the following sentences), which is not the case with Albanian.It is evident that in the Albanian text, a zero morpheme $\varnothing$ corresponds to the German and English personal pronoun, because the Albanian reader already knows to which person the corresponding sentence refers, and similarly to Latin, the predicate can already contain the subject, i.e., 
the subject of a sentence can be omitted if its meaning is already apparent from the context or given by the situation at hand.

It is a peculiarity of the Albanian language that it is more context-dependent and allows its speakers to largely dispense with the use of the personal pronoun, although a highly differentiated pronominal system is available (except it for neuter, which is rendered either by ai (er/he) or ajo (sie/she), depending on whether the noun is masculine or feminine, e.g.:das Kind/ the child (alb.: fëmija) is feminine in Albanian, as well as das Mädchen/the girl (vajza, goca, çupa), das Hemd/the shirt (këmisha), das Heft/the notebook (fletorja), etc.).

Pronominalization in German and English is a cohesion phenomenon because the subject is thematized in every sentence, whereas in Albanian pronominalization is a coherence phenomenon because the subject is not thematized on the text surface. There are cases in Albanian where such pronominalizations are also thematized in the text surface, but only through the so-called short forms of the pronoun (Alb.: trajtat e shkurtra të përemrit) in Akkusativ and Dativ. E.g. Kur $\varnothing$ t'I shkruash (atij), I bën shumë të fala (Wenn du ihm schreiben wirst, richte ihm viele Grüsse von mir aus/When you will write to him, send him many greetings from me). The short form of the pronoun here is $-\mathrm{i}$, in the main and subordinate clauses, which always comes after a zero morpheme and before the finite verb. Unlike pronouns, the so-called short forms of the pronoun cannot be omitted because they serve as a kind of orientation for the object (whether accusative or dative) in the text. In Albanian, there are many short forms of the pronoun: -e, -i, -u, -më, -të, etc. But when two short forms occur in succession in the text, they contract: më $+\mathrm{e}=\mathrm{ma}, \mathrm{te}+\mathrm{e}=\mathrm{ta}, \mathrm{i}+\mathrm{e}=\mathrm{ia}, \mathrm{ju}+\mathrm{e}=$ jua, $\mathrm{u}+\mathrm{e}=\mathrm{ua}$ (these are the forms in the singular); më $+\mathrm{i}=\mathrm{m}^{\prime} \mathrm{i}, \mathrm{te}+\mathrm{i}=$

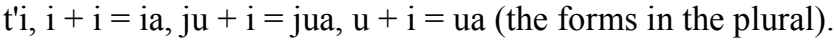

Sometimes it is difficult to establish coherence from the beginning in Albanian when pronouns are completely missing as opening signals in the text. To explain this, I will take a newspaper article as an example:

2) Prishtinë, 7 janar - ØKa tentuar të bëjë vetëvrasje të shtunën vonë, duke pirë Øpërnjëherësh një sasi të madhe të ilaçit për qetësim, por Øi ka shpëtuar më së keqes. Gruaja, me vendbanim në rrugën "Mithat Frashri” në Prishtinë, ka tentuar të vetëvritet të shtunën mbrëma, duke pirë një sasi të tepërt të tabletave për qetësim "Senakas" (5 miligramësh). Ajo është dërguar për trajtim mjekësor në QKU. Mjekët kujdestarë bënë të ditur për "Lajm” se viktima është jashtë rrezikut për jetë, ndërsa tentimi për vetëvrasje kishte ndodhur pas një mosmarrëveshje me vajzën e saj.

(“Lajm”, 08 Januar 2007)

2') Prishtina, 07. Januar - Sie hat versucht, Selbstmord zu begehen, indem sie auf einmal eine große Menge Beruhigungsmittel eingenommen hat, aber sie ist der Gefahr entgangen. Die Frau, die in der Straße „Mithat Frashri“ in Prishtina wohnt, [...] hat versucht, Selbstmord zu begehen, weil sie Streit mit ihrer Tochter gehabt hat.

(Translation: J. A.)

$2^{\text {“) }} \quad$ Prishtina, 07 January - She has tried to commit suicide by taking a large amount of sedatives at once, but she has escaped the danger. The woman who lives in the street "Mithat Frashri" in Prishtina [...] has tried to commit suicide because she had quarrel with her daughter.

(Translation: J. A.)

In this newspaper article there is a cataphoric relation (she ... the woman) and in comparison to the German and English text, where it is thematized from the beginning that it is about a woman (since the article begins with the personal pronoun sie/she) who wanted to commit suicide, the Albanian text is completely incoherent, one does not know whether it is about a man or a woman (since it is not thematized at all in the Albanian text and, as already mentioned, a zero morpheme $\varnothing$ corresponds to the German and English personal pronoun). Only in the fourth sentence is it mentioned that it is about a woman who wanted to commit suicide because she had an argument "with her daughter".

The obligatory es/it, which occurs in German and English in fixed phrases such as: es gibt/there is, es handelt um/it is about, es kommt nicht in Frage/it is not an option, is not rendered by a pronoun in Albanian. It is therefore a zero morpheme. An example from Nur wer liebt, ist lebendig also shows this:

3) Es gibt Schüler einer jungen Philosophie, welche Abende lang in festlichen Häusern sich gemeinsam in großer Zahl der Einheit ihrer Erkenntnis freuen und in begeisterter Schar auf gemeinsam erstiegenen Berghöhen die aufsteigende mütterliche Sonne begrüßen.

(H. Hesse: Nur wer liebt, ist lebendig, Frankfurt/M. p.9)

3') There are disciples of a young philosophy who spend evenings in festive houses rejoicing together in great numbers in the unity of their knowledge and greet the rising maternal sun in enthusiastic crowds on mountain heights they have climbed together.

This text excerpt has been translated in Albanian as follows:

(Translation: J. A.)

3') ØKa nxënës të një filozofie të re, të cilët me net të tëra në pallate solemne i gëzohen së bashku unitetit të njohjes së tyre që e kanë arritur dhe ashtu të entuziazmuar ngjiten bashkërisht mbi majat e maleve për ta përshëndetur diellin përkëdhelës që agon. 
(H. Hesse: I gjallë është vetëm ai që dashuron, Skopje 2006. Translation:Ariton Baftiri, p. 7)

The personal pronoun -es/-it, which occurs in German and English with the impersonal verbs, is also matched in Albanian by a zero morpheme: es schneit/it's snowing -Ø bie borë. Es regnet/it's raining and es schneit/it's snowing is formed in Albanian by the verb bie (fall) + noun borë (snow and rain), for example: *falling snow and rain, respectively; in the other cases such as: es donnert/it thunders and es blitzt/it lightnings there are full verbs also formed without pronouns: bubullin and vetëtin. In passive constructions in German, the optional -es again corresponds to a zero morpheme in Albanian: Es wird ein Haus gebaut (Alb. Ø Ndërtohet një shtëpi).

Weinrich (1993:94) distinguishes between "reference pronouns" and "role pronouns": "An internal structural boundary separates the pronouns for expressing the primary conversational roles speaker ("I") and hearer ("you") from the pronouns for expressing referents in the reference role ("3rd person"). We can therefore call the latter the reference pronouns ("3rd person personal pronouns")" (ibid.). He contrasts the text producer (1st person) and the text recipient (2nd person) as "primary TALK ROLES" with the "REFERENCE ROLE" of the 3rd person as a "residual category that remains vague unless it is given sharper contours by reference (ibid. p. 24). But in Albanian one very often uses the 2nd person pronoun - $t i$ ("you") also referentially, in the sense of Weinrich's reference pronouns. Then this pronoun has the characteristic of indeterminacy, generalization, so means each of us.

The - $t i$ ("you") here takes on the role oftextdeixis in a given conversational situation. Here are some examples that we hear very often in everydayconversational situations in Albanian:

4) Ti flet për ujkun, ujku pas dere

5) Ti s'ke këtë, ti s'ke atë ... e kërkon që Evropa të të pranojë.

6) Ti nuk ke asnjë punim shkencor, dhe më flet mua për cilësi.

In German, this - $t i$ is rendered by the indefinite pronoun -man (Colloquially, there is also this "du" in German: $D a$ redest $\boldsymbol{d u}$ den ganzen Tag, aber die Kinder hören ja doch nicht!(You talk all daylong, but the children don't listen!)). 4' Man redet über den Wolf, der Wolf ist hinter der Tür

5, Man hat das nicht, jenes nicht ... und will, dass ihn Europa aufnimmt

6' Man hat bislang noch keine einzige wissenschaftliche Arbeit geleistet und spricht über Qualität.

In English the German - man corresponds to the indefinite pronoun -one, but mostly we get other forms like: people, you, somebody, etc.

One can also find the use of $-t i$ in this form in some Albanian proverbs:

7 ØBëj mire të gjesh mirë (Wer Gutes tut, erfährt Gutes/Those who do good, experience good)

8 ØPos'mbolle, s'korr (Wer Wind sät, wird Sturm ernten/Who sows wind, will reap storm)

9 ØРо ia bëre varrin tjetrit, do të biesh vetë brenda (Wer anderen eine Grube gräbt, fällt selbst hinein/He who digs a pit for others falls into it himself)

10 ØРos'punove në verë, nuk ke për dimër (Wer nicht im Sommer sammelt ein, der wird im Winter dürftig sein/He who does not collect in summer, will be meager in winter)

In these proverbs, the personal pronoun - $t i$ is not thematized, so it is a zero morpheme. One notices, however, by the verb endings that it is about the imperative 2 nd person singular (first proverb): $b \ddot{e}+j$; or about the subjunctive II (present or past tense) (in the 2nd 3rd and 4th proverb): mbjell-mbolle, bëj-bëre, punoj-punove.

\section{Conclusions}

Although German, English and Albanian belong to the same language family, they have their own peculiarities and turn out to have obvious contrasts in the syntagmatic level. While the pronoun as part of speech morphologically does not differ much in Albanian from German and English, however in its function as an element of textual constitution it has great divergences compared to the two languages examined in this paper. In German and English, the pronoun is an element of text cohesion, while in Albanian it is an element of textual coherence, because in Albanian the subject, but also other sentence complements are not necessarily thematized on the surface of the text, so they are in mind, especially to avoid of repetitions and for reasons of textual stylistics.

In the didactic aspect, this paper shows a special importance, because it raises issues not only formal but also functional, especially in the use of pronouns in concrete texts, intertwining the deep structures of language, which vary from language to language. Albanian has its own linguistic mechanism like German and English and any inappropriate use of the pronoun as part of the speech can significantly affect the disturbance of textual coherence.

\section{References}

Adamzik, K. (2004): Textlinguistik. EineeinführendeDarstellung. Tübingen: Niemeyer.

Akademia e Shkencave të R. së Shqipërisë. Instituti i gjuhësisë dhe letërsisë. (1995): Gramatika e gjuhës shqipe I. Tiranë.

Akademia e Shkencave të R. së Shqipërisë. Instituti i gjuhësisë dhe letërsisë. (1997): Gramatika e gjuhës shqipe II. Tiranë.

Beaugrande, R. A. de / Dressler, W. U. (1981): Einführung in Textlinguistik. Tübigen: GuntherNarr. 
Çeliku, A. (2005): Koherenca tekstore. Hyrje në konceptet bazë të gjuhësisë së tekstit nëpërmjet një qasjeje krahasuese të shqipes me gjermanishten. Asdreni Shkup.

Çeliku, A. (2009):HerstellungvonTextkohärenz im Deutschen und im Albanischen. PeterLang Frankfurt amMain. Dibra, K. / Varfi, N. (1999): Gjuhësi teksti, Tiranë: shblu.

Heinemann, W. / Viehweger, D. (1991): Textlinguistik. Tübingen: Niemeyer.

Heinemann, M. / Heinemann, W. (2002): Grundlagen der Textlinguistik: Interaktion-Text-Diskurs. Tübingen: Niemeyer.

Rickheit, G. (2000): "Kohärenz und Kohäsion” In: Brinker, K. / Antos, G. / Heinemann, W. / Sager, S. F. (Hg.): Text- und Gesprächslinguistik. HSK-Bd. 16.1. Berlin / New York, 275-283.

Weinrich, H. (1993): Textgrammatik der deutschen Sprache. Mannheim. 